Article

\title{
Nitrogen Removal from Micro-Polluted Reservoir Water by Indigenous Aerobic Denitrifiers
}

\author{
Ting-Lin Huang *, Shi-Lei Zhou, Hai-Han Zhang, Na Zhou, Lin Guo, Shi-Yu Di and Zi-Zhen Zhou
}

School of Environmental and Municipal Engineering, Xi'an University of Architecture and Technology, Xi'an 710055, China; E-Mails: ZSLZhouShilei@126.com (S.-L.Z.); zhanghaihan@xauat.edu.cn (H.-H.Z.); zhounastone@163.com (N.Z.); guolin9608@aliyun.com (L.G.); dishiyu0924@gmail.com (S.-Y.D.); zhouzizhen001@sina.com (Z.-Z.Z.)

* Author to whom correspondence should be addressed; E-Mail: huangtinglin@xauat.edu.cn; Tel.: +86-29-8220-1038; Fax: +86-29-8220-2729.

Academic Editor: Guido R. M. M. Haenen

Received: 16 February 2015 / Accepted: 31 March 2015 / Published: 10 April 2015

\begin{abstract}
Treatment of micro-polluted source water is receiving increasing attention because of environmental awareness on a global level. We isolated and identified aerobic denitrifying bacteria Zoogloea sp. N299, Acinetobacter sp. G107, and Acinetobacter sp. 81Y and used these to remediate samples of their native source water. We first domesticated the isolated strains in the source water, and the 48-h nitrate removal rates of strains N299, G107, and $81 \mathrm{Y}$ reached $33.69 \%, 28.28 \%$, and $22.86 \%$, respectively, with no nitrite accumulation. We then conducted a source-water remediation experiment and cultured the domesticated strains (each at a dry cell weight concentration of $0.4 \mathrm{ppm}$ ) together in a sample of source water at $20-26^{\circ} \mathrm{C}$ and a dissolved oxygen concentration of 3-7 mg/L for 60 days. The nitrate concentration of the system decreased from $1.57 \pm 0.02$ to $0.42 \pm 0.01 \mathrm{mg} / \mathrm{L}$ and that of a control system decreased from $1.63 \pm 0.02$ to $1.30 \pm 0.01 \mathrm{mg} / \mathrm{L}$, each with no nitrite accumulation. Total nitrogen of the bacterial system changed from $2.31 \pm 0.12$ to $1.09 \pm 0.01 \mathrm{mg} / \mathrm{L}$, while that of the control system changed from $2.51 \pm 0.13$ to $1.72 \pm 0.06 \mathrm{mg} / \mathrm{L}$. The densities of aerobic denitrification bacteria in the experimental and control systems ranged from $2.8 \times 10^{4}$ to $2 \times 10^{7} \mathrm{cfu} / \mathrm{mL}$ and from $7.75 \times 10^{3}$ to $5.5 \times 10^{5} \mathrm{cfu} / \mathrm{mL}$, respectively. The permanganate index in the experimental and control systems decreased from $5.94 \pm 0.12$ to $3.10 \pm 0.08 \mathrm{mg} / \mathrm{L}$ and from $6.02 \pm 0.13$ to $3.61 \pm 0.11 \mathrm{mg} / \mathrm{L}$, respectively, over the course of the experiment. Next, we supplemented samples of the experimental and control systems with additional bacteria or additional
\end{abstract}


source water and cultivated the systems for another 35 days. The additional bacteria did little to improve the water quality. The additional source water provided supplemental carbon and brought the nitrate removal rate in the experimental system to $16.97 \%$, while that in the control system reached only $3.01 \%$, with no nitrite accumulation in either system. Our results show that aerobic denitrifying bacteria remain highly active after domestication and demonstrate the applicability of such organisms in the bioremediation of oligotrophic ecosystems.

Keywords: aerobic denitrifiers; aerobic denitrification; nitrogen removal; source water

\section{Introduction}

Economic and social development has resulted in massive amounts of nitrogenous compounds in environmental waters and led to the continuous deterioration of aquatic ecosystems [1-5] and eutrophication of some reservoirs [6,7], putting drinking water sources at great risk [5]. Many physical [8], chemical [9], and biological methods [10] have been used to remove the nitrogenous compounds and purify polluted waters [11]. Bioremediation has attracted wide attention because it has lower maintenance costs and greater pollutant-removal performance than other methods [10], for example, remediation of uranium [12], toluene [13,14], and organic and metal contamination [15]. Traditional denitrification occurs under anaerobic or anoxic conditions [16] through a sequence of intermediates (nitrate, nitrite, nitric oxide, and nitrous oxide), finally ending with nitrogen gas [17-19].

The reaction steps that use nitrate or nitrite as terminal electron acceptors are inhibited by oxygen [20]. Paracoccus pantotrophus, first isolated by Robertson and Kuenen [21] and later renamed as Thiosphaera pantotropha, is an aerobic denitrifier that has been studied to the greatest extent. There have been recent reports of aerobic denitrifying bacteria isolated from canals [22], soils [23], ponds [24], activated sludge [25], and lakes [26] that can simultaneously utilize oxygen and nitrate as electron acceptors. Most of the isolated strains, such as T. pantotropha [27], Alcaligenes faecalis [25,28,29], Pseudomonas stutzeri [22], Pseudomonas putida [23,30], Pseudomonas mendocina [24], Pseudomonas aeruginosa [31], Citrobacter diversus [32], and Bacillus subtilis [33,34], have been used to treat wastewater [25]. Patureau et al. [35] proposed a more integrated configuration for nitrogen and phosphorus removal through the introduction of an aerobic denitrifier into a complex phosphorus/nitrifying ecosystem. Barak et al. [36] concluded that Pseudomonas denitrificans is capable of combined phosphate and nitrate removal without the need for alternating anaerobic/aerobic or anaerobic/anoxic switches. Joo et al. [25] found that $P$. denitrificans removed more than $65 \%$ of the ammonia from polluted water and showed that one strain performed heterotrophic nitrification and aerobic denitrification in piggery wastewater.

However, these strains might have acclimation problems in eutrophic freshwater reservoirs because of the relatively low nitrate and ammonium concentrations and low carbon levels, which could limit the denitrification process [37]. Indigenous strains that can perform aerobic denitrification in micro-polluted reservoir water would help to overcome this problem.

Aerobic denitrifiers are rarely isolated from reservoirs [26,38], and there is little or no research to date on the use of aerobic denitrifiers to denitrify and bioremediate reservoir ecosystems. Several studies have 
illustrated the difficulties in removing nitrogen from source waters because of the relatively low concentrations of nitrogen as a pollutant $[39,40]$. We studied the effects of aerobic denitrifiers on water quality, and some of our previous findings have been reported elsewhere [41-45]. The objective of this study was to determine the phylogenetic affiliation of three strains of indigenous aerobic denitrifiers by using $16 \mathrm{~S}$ rRNA sequencing and to assess the nitrogen removal performance of these strains in micro-polluted reservoir water.

\section{Results}

\subsection{Identification and Phylogenetic Analysis of Three Aerobic Denitrifiers}

Three gram-negative, oligotrophic aerobic denitrifying bacterial strains were isolated, submitted to GenBank, and identified as Zoogloea sp. N299, Acinetobacter sp. G107, and Acinetobacter sp. 81Y (Table 1). The sizes of the three strains were approximately $0.5-1 \mu \mathrm{m} \times 1.5-3 \mu \mathrm{m}, 0.5-1 \mu \mathrm{m} \times 1-1.5 \mu \mathrm{m}$, and $0.5-1 \mu \mathrm{m} \times 2-8 \mu \mathrm{m}$ (Figure 1). Figure 2 shows the neighbor-joining phylogenetic tree prepared using partial 16S rRNA gene sequences from strains N299, G107, and 81Y, type culture strains and other previously studied aerobic denitrifiers. On the basis of the 16S rRNA gene sequences, strain N299 clustered with species from Zoogloea and strains G107 and 81Y clustered with species from Acinetobacter.

Table 1. 16S rRNA sequence similarities between the isolates and reference sequences.

\begin{tabular}{ccccc}
\hline Strains & GenBank No. & Sequence Length & Reference Sequences & Similarity (\%) \\
\hline 81 Y & KP717097 & 1315 & Acinetobacter pittii CIP 70.29(T) & 99.92 \\
G107 & KP717096 & 1392 & Acinetobacter pittii CIP 70.29(T) & 99.57 \\
N299 & KP717093 & 1361 & Zoogloea caeni EMB43(T) & 97.85 \\
\hline
\end{tabular}

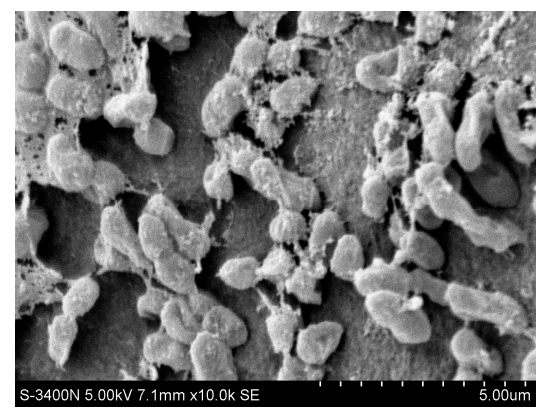

N299

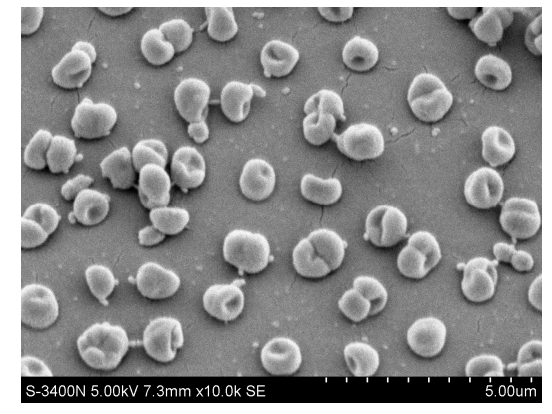

G107

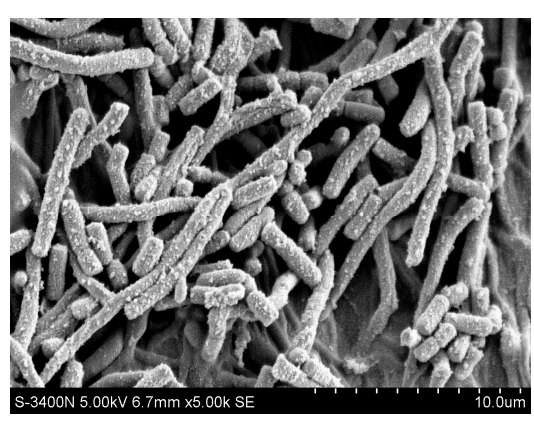

$81 \mathrm{Y}$

Figure 1. Scanning electron microscope images of the aerobic denitrifiers. 


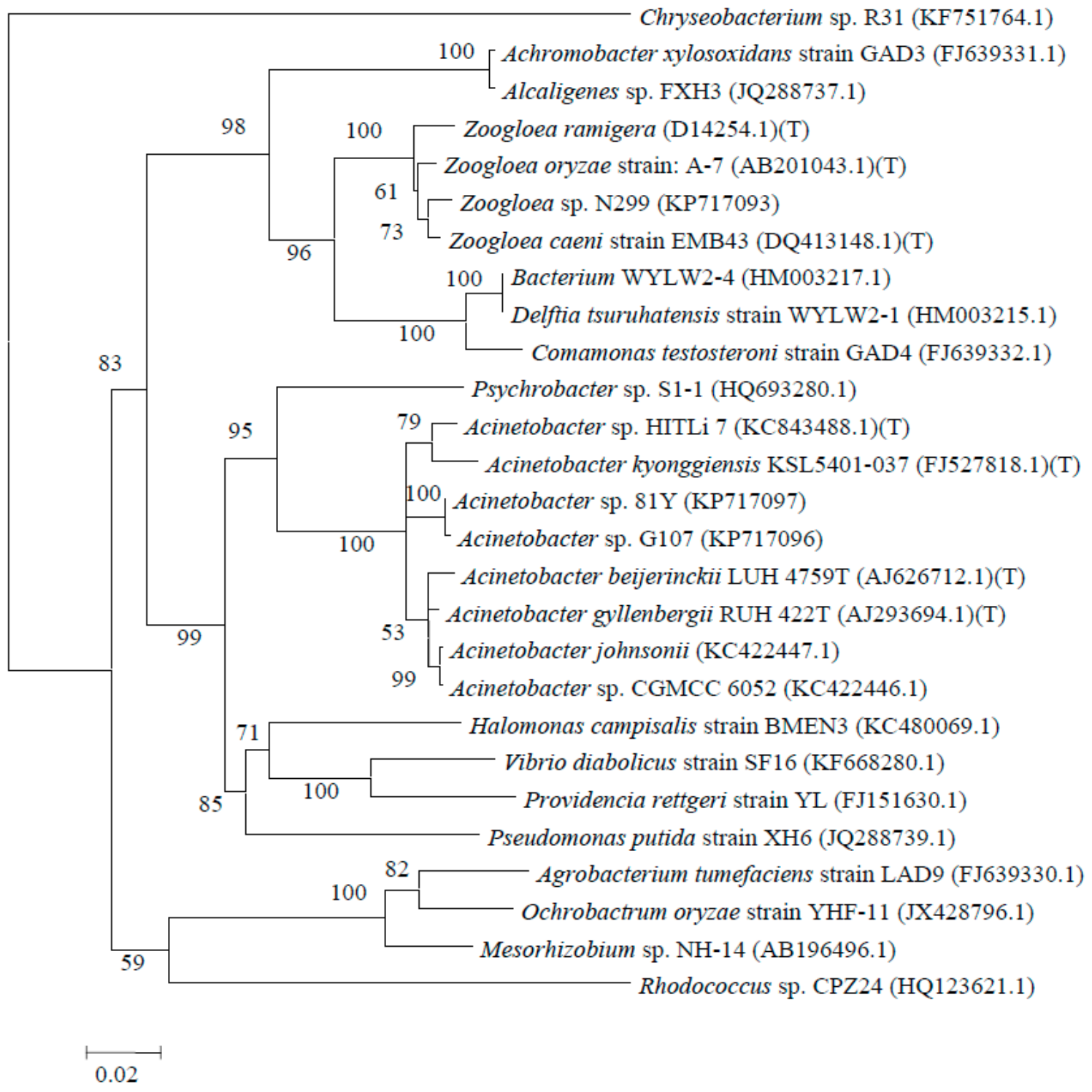

Figure 2. Phylogenetic tree based on the comparison of partial 16S rRNA gene sequences of strains N299, G107, and 81Y, other type culture strains, and other previously studied aerobic denitrifiers. The tree was constructed using the neighbour-joining method with bootstrap values of 1000 replications.

\subsection{Gradient Domestication}

Strains N299, G107, and 81Y were adapted to the source water environment by gradient domestication, which lasted 12 days. The nitrate removal rates of $\mathrm{N} 299, \mathrm{G} 107$, and $81 \mathrm{Y}$ during the $100 \%$ source-water domestication experiment were $33.69 \%, 28.28 \%$, and $22.86 \%$, respectively, in $48 \mathrm{~h}$, and no nitrite was accumulated in the cultures (Figures 3 and 4). The densities of the three strains in the source water at the end of the domestication was $10^{6 \sim 7} \mathrm{cfu} / \mathrm{mL}$, providing a good preparation for the subsequent experiments (Table 2). 
Table 2. Indicators of bacterial densities in the $100 \%$ source water domestication cultures.

\begin{tabular}{ccccc}
\hline Strains & Colonies/Lg & SD & DCW/(mg/mL) & SD \\
\hline N299 & 6.78 & 0.01 & 0.39 & 0.04 \\
G107 & 6.41 & 0.07 & 0.48 & 0.06 \\
81Y & 6.76 & 0.03 & 0.42 & 0.06 \\
\hline
\end{tabular}

SD: Standard deviation of three replicates; DCW: Dry cell weight of three replicates.
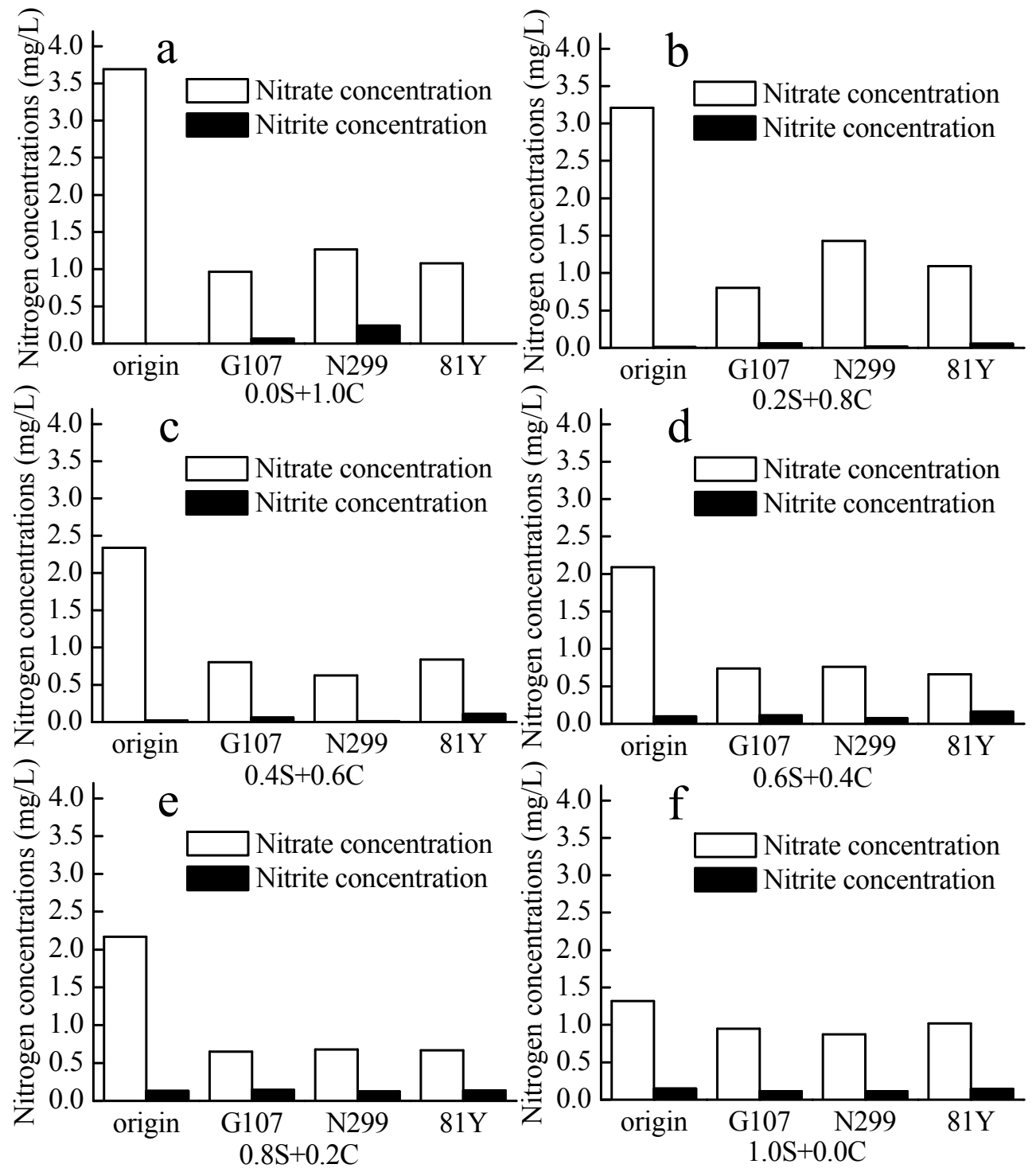

Figure 3. The nitrate and nitrite concentrations in domestication of the source water experiment. (a) $0.0 \mathrm{~S}+1.0 \mathrm{C}$ represents $0 \%$ source water $+100 \%$ culture medium; (b) $0.2 \mathrm{~S}+0.8 \mathrm{C}$ represents $20 \%$ source water $+80 \%$ culture medium; (c) $0.4 \mathrm{~S}+0.6 \mathrm{C}$ represents $40 \%$ source water $+60 \%$ culture medium; (d) $0.6 \mathrm{~S}+0.4 \mathrm{C}$ represents $60 \%$ source water $+40 \%$ culture medium; (e) $0.8 \mathrm{~S}+0.2 \mathrm{C}$ represents $80 \%$ source water + $20 \%$ culture medium; (f) $1.0 \mathrm{~S}+0.0 \mathrm{C}$ represents $100 \%$ source water $+0 \%$ culture medium. 

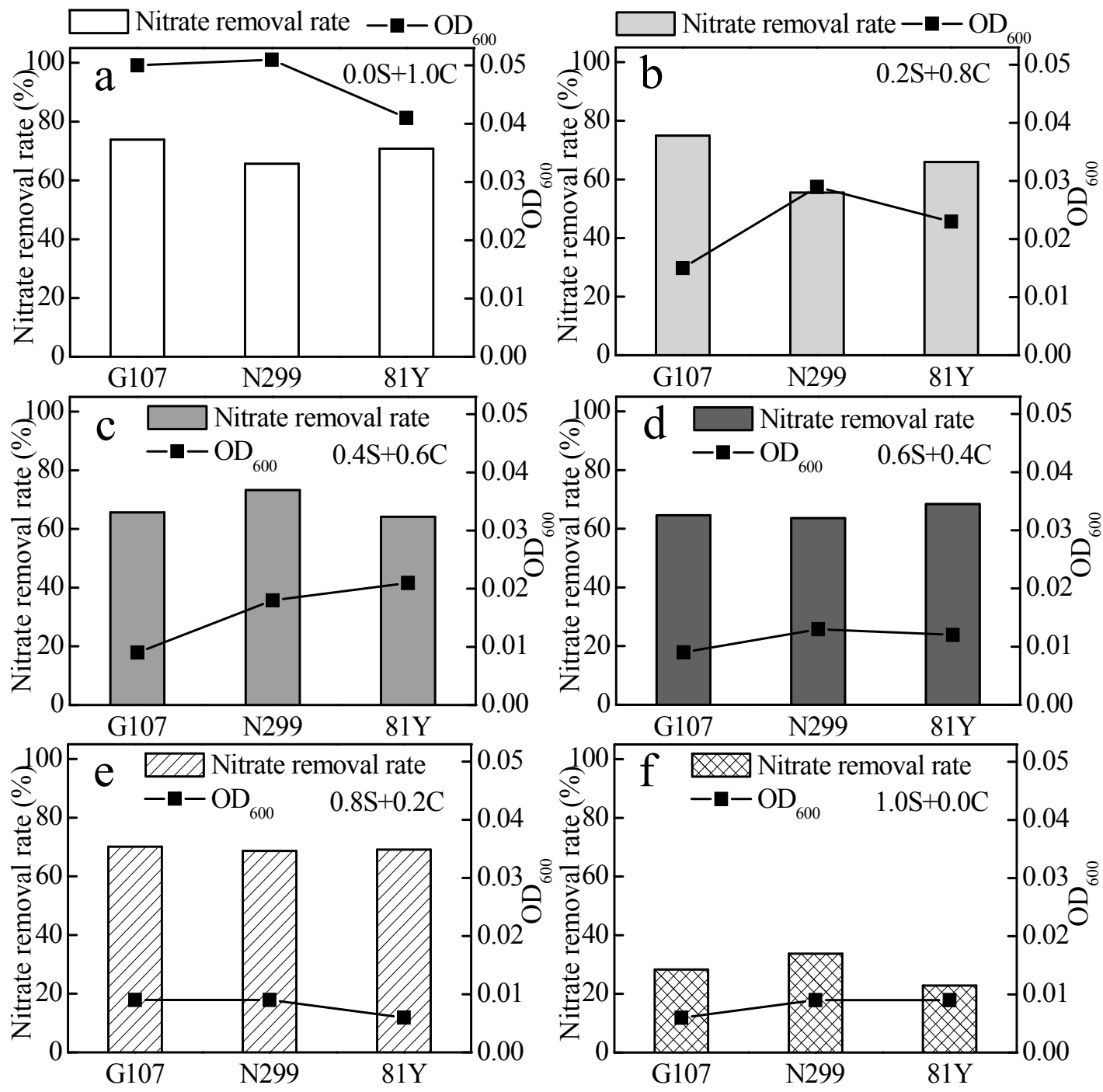

Figure 4. The nitrate removal and $\mathrm{OD}_{600}$ in domestication of the source water experiment. (a) $0.0 \mathrm{~S}+1.0 \mathrm{C}$ represents $0 \%$ source water $+100 \%$ culture medium; (b) $0.2 \mathrm{~S}+0.8 \mathrm{C}$ represents $20 \%$ source water $+80 \%$ culture medium; (c) $0.4 \mathrm{~S}+0.6 \mathrm{C}$ represents $40 \%$ source water $+60 \%$ culture medium; (d) $0.6 \mathrm{~S}+0.4 \mathrm{C}$ represents $60 \%$ source water + $40 \%$ culture medium; (e) $0.8 \mathrm{~S}+0.2 \mathrm{C}$ represents $80 \%$ source water $+20 \%$ culture medium; (f) $1.0 \mathrm{~S}+0.0 \mathrm{C}$ represents $100 \%$ source water $+0 \%$ culture medium.

\subsection{Dissolved Oxygen Concentration and Temperature in the Source Water Denitrification Experiment}

In the 60-day source water denitrification experiment, the temperature of the experimental system and the control system was $20-27^{\circ} \mathrm{C}$, and the dissolved oxygen concentration (DOC) of the two systems was maintained at 3-7 mg/L (Figure 5).

\subsection{Nitrate and Total Nitrogen Concentrations in the Source Water Denitrification Experiment}

Nitrate and total nitrogen (TN) concentrations in the source water in the experimental system and control system reached a stable state after 30 days, which lasted until the end of the 60-day experiment (Figures 6 and 7). In the first 30 days, nitrate concentration in the experimental system decreased from 
$1.57 \pm 0.02$ to $0.38 \pm 0.01 \mathrm{mg} / \mathrm{L}$, while that in the control system decreased from $1.63 \pm 0.02$ to $1.18 \pm 0.03 \mathrm{mg} / \mathrm{L}$. At the end of the 60 -day experiment, nitrate concentration in the experimental and control systems was $0.42 \pm 0.01$ and $1.30 \pm 0.01 \mathrm{mg} / \mathrm{L}$, respectively. During the first 30 days of the experiment, the nitrate removal rate in the experimental system was at least $70 \%$, while that in the control system was around $20 \%$. TN in the experimental system was significantly lower than that in the control system (Figure 7). At the end of the 60-day experiment, TN in the experimental system was $1.09 \pm 0.01 \mathrm{mg} / \mathrm{L}$, while that in the control system was $1.72 \pm 0.06 \mathrm{mg} / \mathrm{L}$. TN removal rate in the experimental system averaged about $50 \%$, while that in the control system was $20 \%-30 \%$.
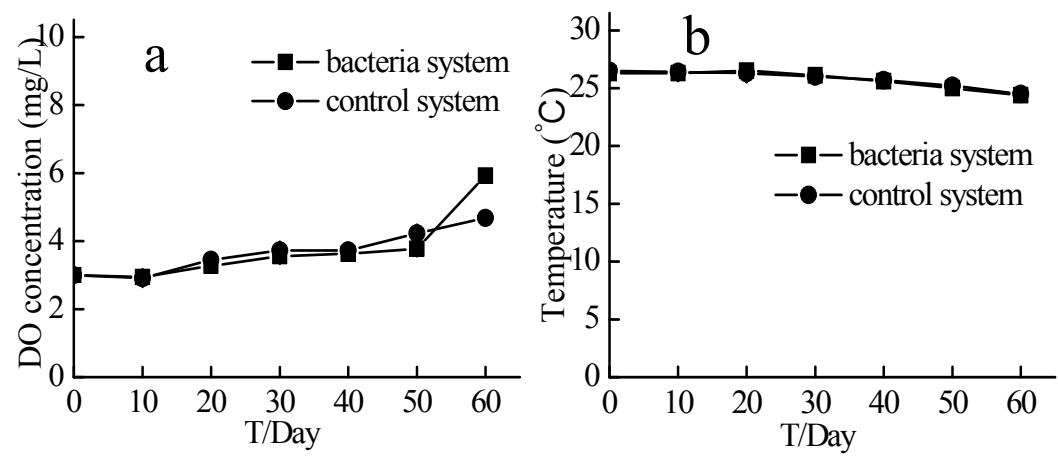

Figure 5. DO and Temperature of the source water experiment. Bacteria system respents system with aerobic denitrification bacteria N299, G107 and 81Y; Control system respents system without aerobic denitrification bacteria N299, G107 and 81Y; (a) DO concentration of bacteria and control system; (b) Temperature of bacteria and control system.
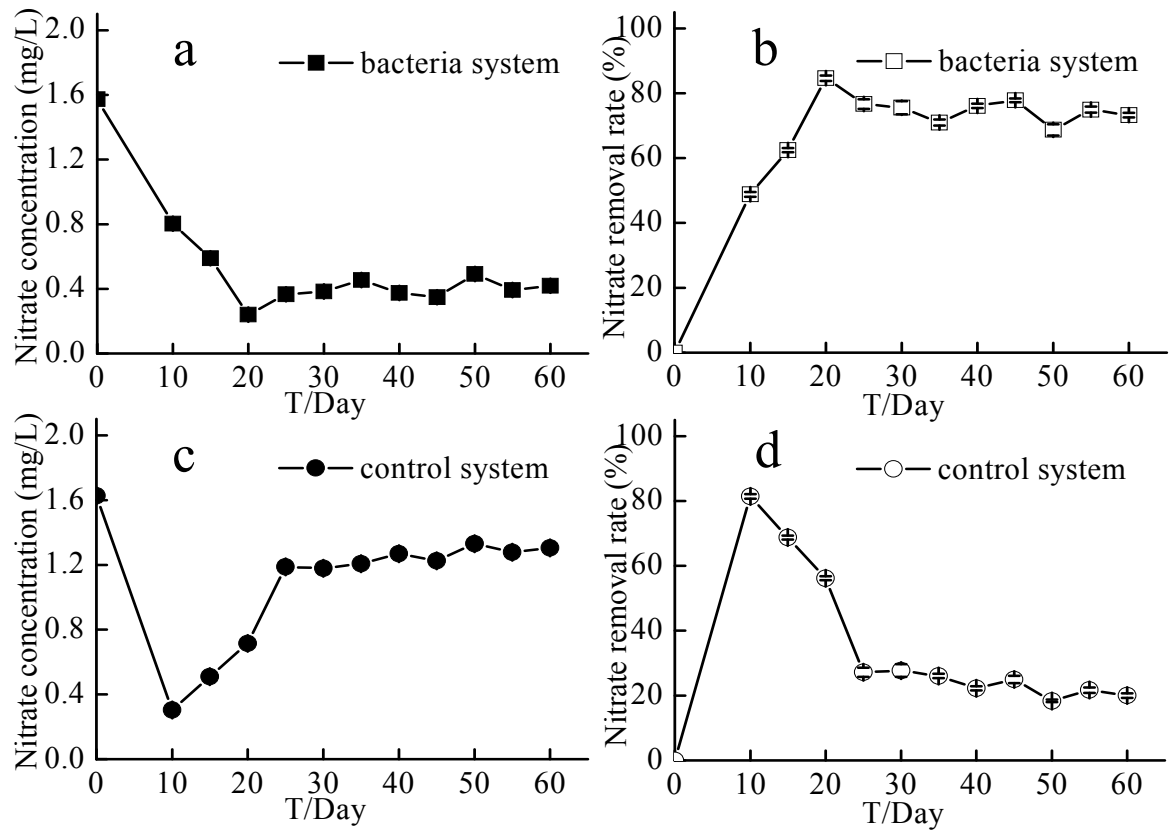

Figure 6. Nitrate concentrations and nitrate removal rates of the source water experiment. Bacteria system respents system with aerobic denitrification bacteria N299, G107 and 81Y; Control system respents system without aerobic denitrification bacteria N299, G107 and 81Y;

(a) nitrate concentration of bacteria system; (b) nitrate removal rate of bacteria system; (c) nitrate concentration of control system; (d) nitrate removal rate of control system. 

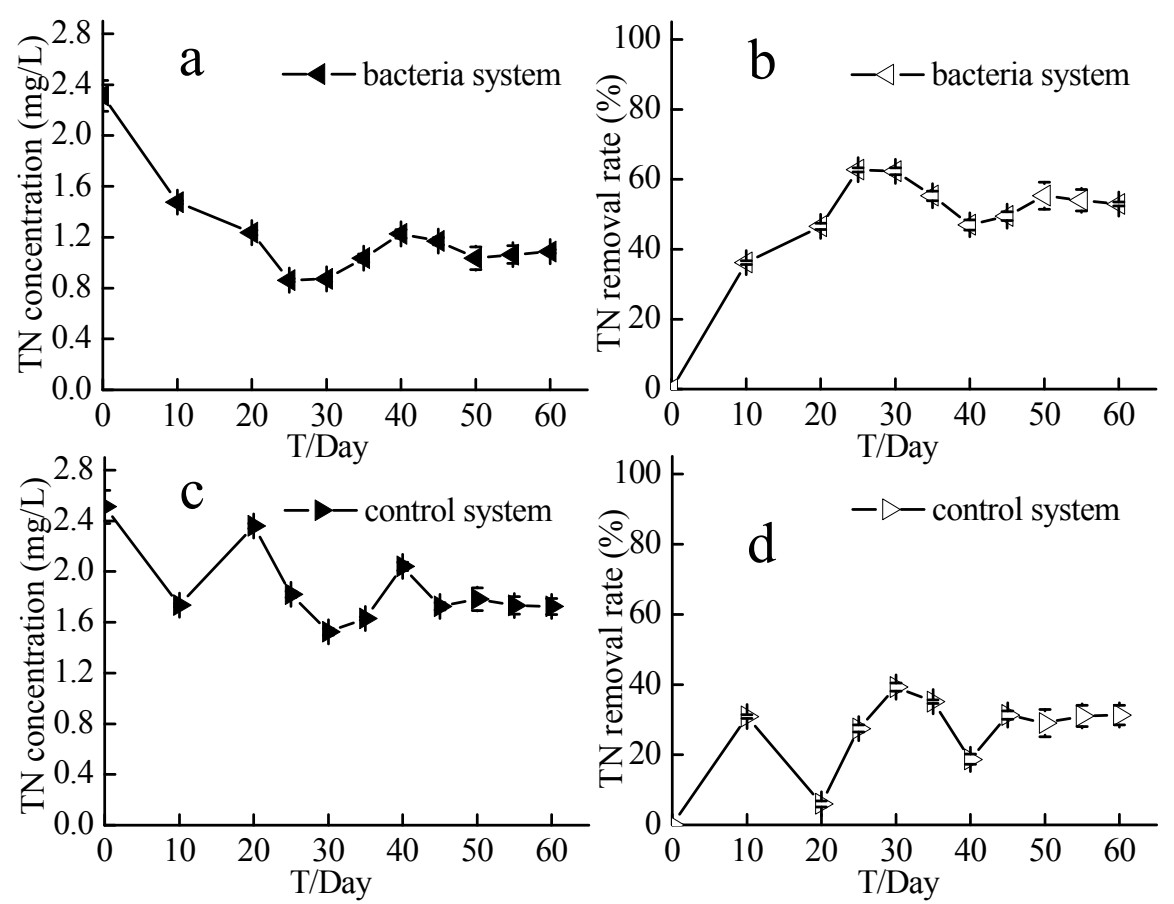

Figure 7. $\mathrm{TN}$ concentrations and $\mathrm{TN}$ removal rates of the source water experiment. Bacteria system respents system with aerobic denitrification bacteria N299, G107 and 81Y; Control system respents system without aerobic denitrification bacteria N299, G107 and 81Y;

(a) $\mathrm{TN}$ concentration of bacteria system; (b) TN removal rate of bacteria system;

(c) TN concentration of control system; (d) TN removal rate of control system.

\subsection{Nitrite, Permanganate Index, and Bacterial Densities in the Source Water Denitrification Experiment}

As shown in Figure 8, nitrite concentration in the experimental system increased from $0.07 \pm 0.01$ to $0.59 \pm 0.01 \mathrm{mg} / \mathrm{L}$ in 15 days and then decreased to $0.03 \pm 0.00 \mathrm{mg} / \mathrm{L}$, while that in the control system increased from $0.08 \pm 0.01$ to $0.55 \pm 0.01 \mathrm{mg} / \mathrm{L}$ and then decreased to $0 \pm 0.00 \mathrm{mg} / \mathrm{L}$. The permanganate index $\left(\mathrm{COD}_{\mathrm{Mn}}\right)$ in the experimental system decreased from $5.94 \pm 0.12$ to $3.10 \pm 0.08 \mathrm{mg} / \mathrm{L}$, while that in the control system decreased from $6.02 \pm 0.13$ to $3.61 \pm 0.11 \mathrm{mg} / \mathrm{L}$. The density of aerobic denitrifying bacteria in the experimental system was higher than that in the control system, particularly at day 50 when the density in the experimental system reached $4.36 \times 10^{8} \mathrm{cfu} / \mathrm{mL}$ and that in the control system was $1.87 \times 10^{6} \mathrm{cfu} / \mathrm{mL}$.

\subsection{Experiment with Supplemental Bacteria}

The temperature of the experimental and control systems was $26-28{ }^{\circ} \mathrm{C}$ over the course of the experiment. At the end of the 35-day experiment, the system supplemented with additional bacteria contained $0.5 \mathrm{mg} / \mathrm{L}$ nitrate, $0 \mathrm{mg} / \mathrm{L}$ nitrite, and $\sim 1.0 \mathrm{mg} / \mathrm{L} \mathrm{TN}$ (Tables 3 and 4 ). The control system contained $\sim 1.5 \mathrm{mg} / \mathrm{L}$ nitrate at the end of the experiment, and the nitrate removal rate was less than $20 \%$, which was consistent with the previous control system. There was no nitrite detected in the control system, and the TN removal rate was about $20 \%$. 

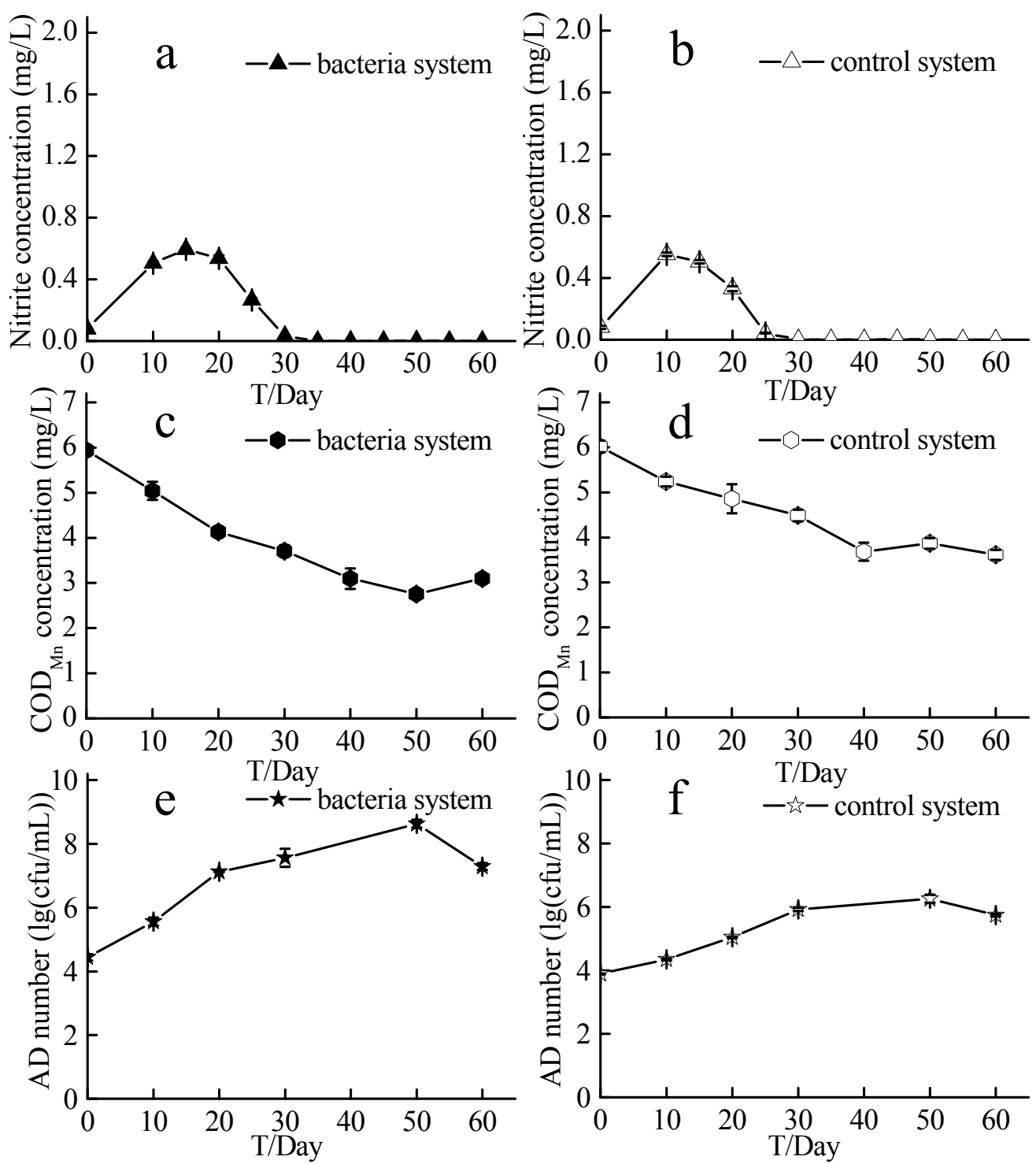

Figure 8. Nitrite concentrations, $\mathrm{COD}_{\mathrm{Mn}}$, and the densities of aerobic denitrification bacteria of the source water experiment. AD number represents the densities of aerobic denitrification bacteria; Bacteria system represents the system with aerobic denitrification bacteria N299, G107 and 81Y; Control system means system without aerobic denitrification bacteria N299, G107 and 81Y; (a) nitrite concentration of bacteria system; (b) nitrite concentration of

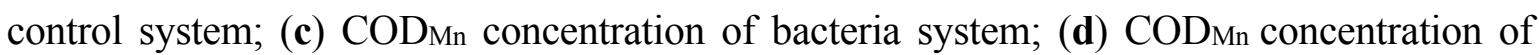
control system; (e) AD number of bacteria system; (f) AD number of control system.

Table 3. The results of addition bacteria system.

\begin{tabular}{ccccccccc}
\hline Day & $\begin{array}{c}\text { Nitrate } \\
(\mathbf{m g} / \mathbf{L})\end{array}$ & $\begin{array}{c}\text { Nitrate Removal } \\
\text { Rate (\%) }\end{array}$ & Nitrite (mg/L) & TN (mg/L) & $\begin{array}{c}\text { TN Removal } \\
\text { Rate (\%) }\end{array}$ & COD & DO (mg/L) & T $\left({ }^{\circ} \mathbf{C}\right)$ \\
\hline 0 & 0.61 & 61.15 & 0 & 1.04 & 48.26 & 3.65 & 7.23 & 27.20 \\
10 & 0.48 & 69.43 & 0 & 1.51 & 24.88 & 3.13 & 5.94 & 28.40 \\
\hline 20 & 0.63 & 60.18 & 0.02 & 1.53 & 23.72 & 3.03 & 5.46 & 25.5 \\
30 & 0.51 & 67.57 & 0.01 & 1.02 & 49.46 & 2.95 & 6.82 & 28.3 \\
35 & 0.46 & 70.42 & 0 & - & - & 2.92 & 7.03 & 26.0 \\
\hline
\end{tabular}


Table 4. The results of the control system.

\begin{tabular}{ccccccccc}
\hline Day & $\begin{array}{c}\text { Nitrate } \\
(\mathbf{m g} / \mathbf{L})\end{array}$ & $\begin{array}{c}\text { Nitrate Removal } \\
\text { Rate (\%) }\end{array}$ & Nitrite (mg/L) & TN (mg/L) & $\begin{array}{c}\text { TN Removal } \\
\text { Rate (\%) }\end{array}$ & COD & DO (mg/L) & T ( $\left.{ }^{\circ} \mathbf{C}\right)$ \\
\hline 0 & 1.41 & 13.50 & 0.001 & 1.61 & 35.86 & 3.83 & 6.50 & 26.20 \\
10 & 1.28 & 21.47 & 0 & 2.56 & -1.99 & 2.47 & 6.90 & 27.90 \\
20 & 1.72 & -5.76 & 0.01 & 2.31 & 7.99 & 2.00 & 8.18 & 27.50 \\
30 & 1.40 & 13.97 & 0.04 & 1.85 & 26.31 & 2.25 & 7.27 & 27.70 \\
35 & 1.72 & -5.76 & 0 & - & - & 2.32 & 7.67 & 27.40 \\
\hline
\end{tabular}

-, no detected.

\subsection{Supplemental Carbon Experiment}

Nitrate concentration in the experimental system dropped from $1.42-1.18 \mathrm{mg} / \mathrm{L}$, while that in the control system dropped from 1.63-1.58 mg/L (which was essentially unchanged; Figure 9). At the end of the 35-day experiment, the nitrate removal rate in the experimental system was $16.97 \%$, while that in the control system was $3.01 \%$. After 10 days, nitrite levels in the two systems were both very low, at $0.02 \mathrm{mg} / \mathrm{L}$ or less (Figure 10a). The COD $\mathrm{Mn}$ in the experimental system decreased from 3.3-2.17 mg/L, and that in the control system decreased from 3.57-2.22 $\mathrm{mg} / \mathrm{L}$ (Figure 10b). The temperature of the cultures ranged from $22-11^{\circ} \mathrm{C}$, and the DOC was $3.8-7.3 \mathrm{mg} / \mathrm{L}$ (Figure $10 \mathrm{c}, \mathrm{d}$ ).
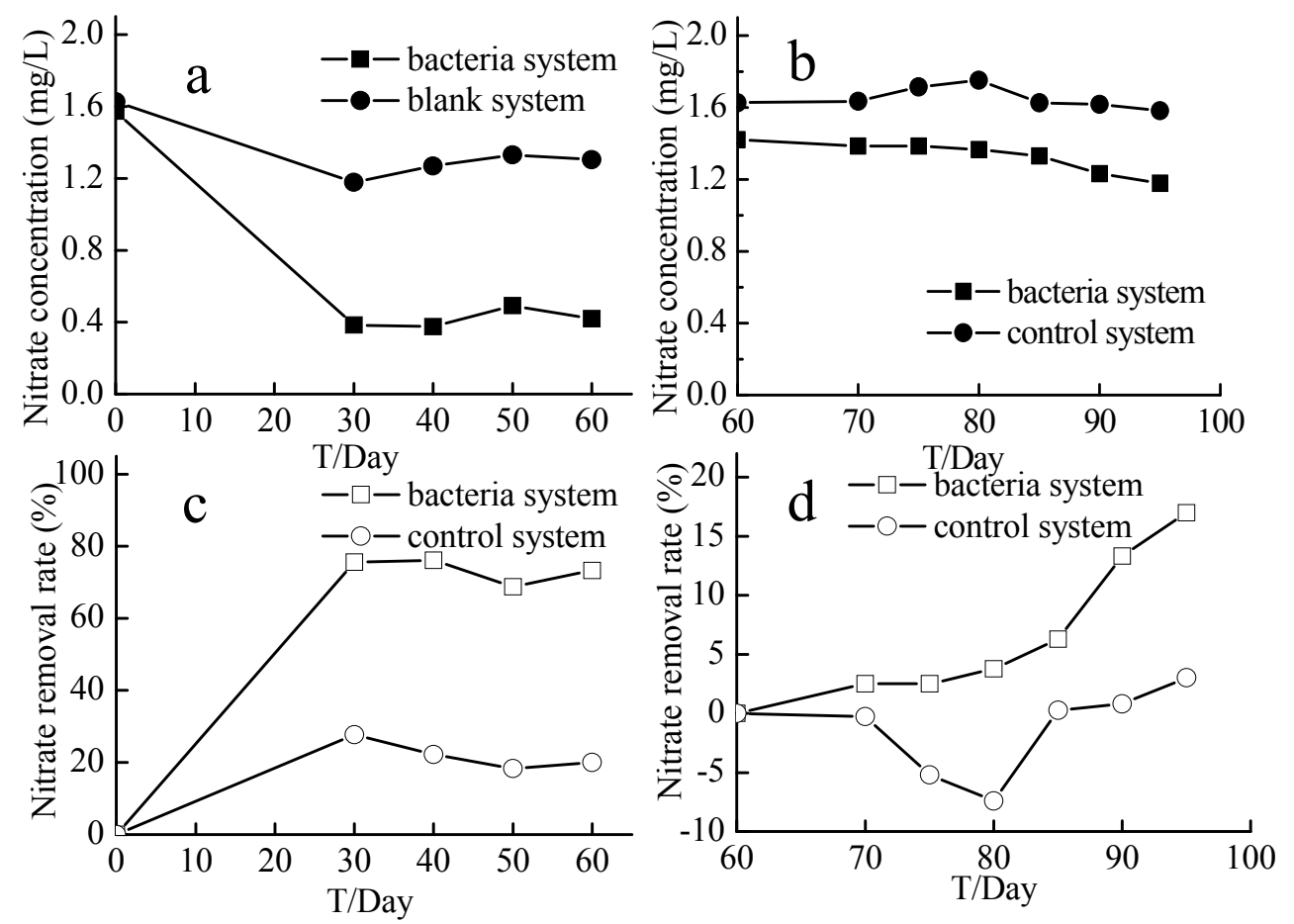

Figure 9. Nitrate concentrations and nitrate removal rates of the supplemental carbon experiment. Bacteria system means system with aerobic denitrification bacteria N299, G107 and 81Y; Control system means system without aerobic denitrification bacteria N299, G107 and 81Y; (a) nitrate concentration of bacteria and control system (0 60 days); (b) nitrate concentration of bacteria and control system (60 95 days); (c) nitrate removal rate of bacteria and control system (0 60 days); (d) nitrate removal rate of bacteria and control system (60 95 days). 

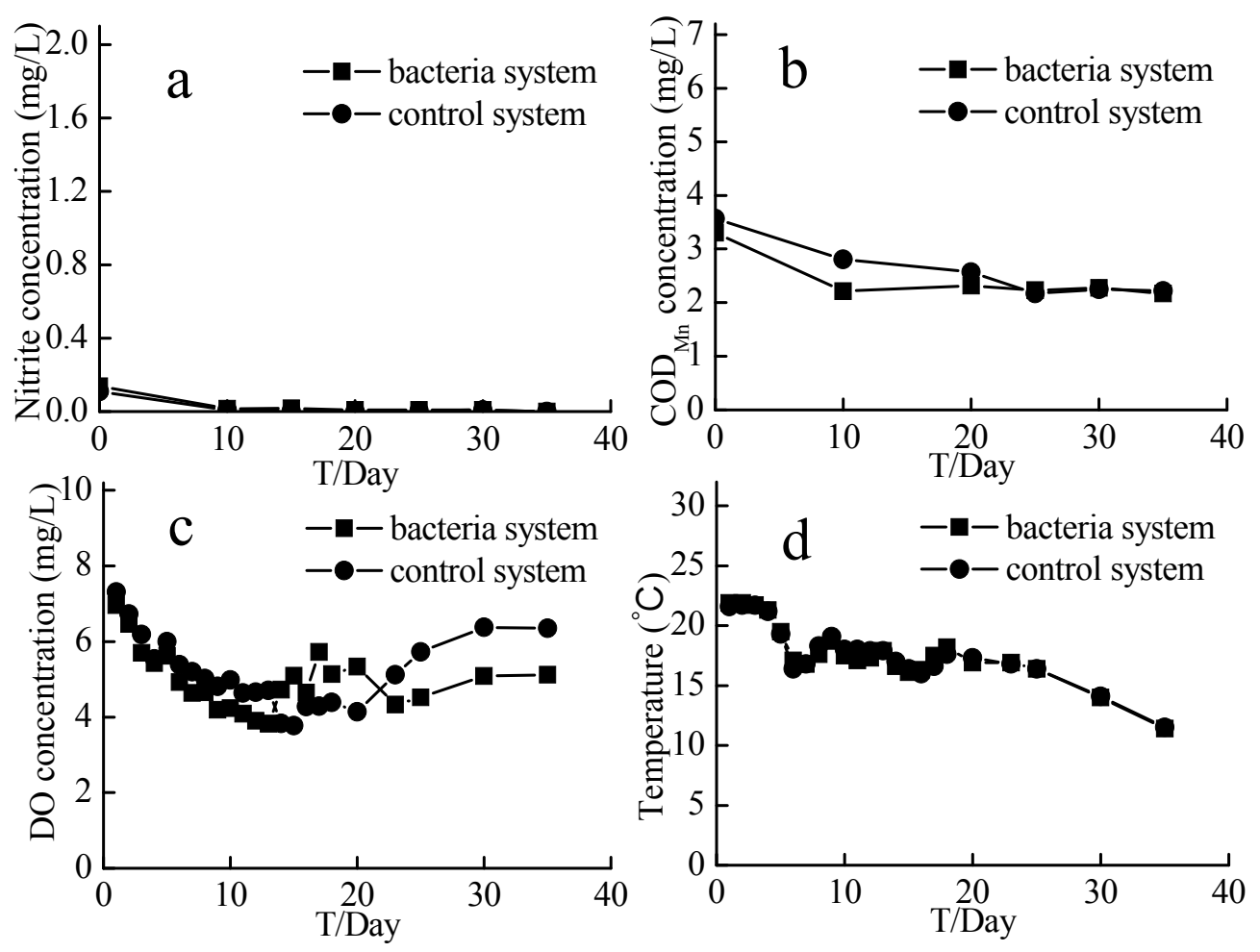

Figure 10. The nitrite, $\mathrm{COD}_{\mathrm{Mn}}$, Temperature, and DO of the supplemental carbon experiment. Bacteria system represents system with aerobic denitrification bacteria N299, G107 and 81Y; Control system means system without aerobic denitrification bacteria N299, G107 and 81Y; (a) nitrite concentration of bacteria and control system; (b) CODMn concentration of bacteria and control system; (c) DO concentration of bacteria and control system; (d) Temperature of bacteria and control system.

\section{Discussion}

Through enrichment and domestication of reservoir sediments, total organic carbon (TOC) of the final system was almost $13 \mathrm{mg} / \mathrm{L}$. Then, the aerobic denitrifying bacteria were domesticated [45] by a series of transfers through the following media concentrations: 100\% culture medium (SM medium, $\sim 30 \mathrm{mg} / \mathrm{L}$ carbon source), $80 \%$ culture medium $+20 \%$ source water $(25.2 \mathrm{mg} / \mathrm{L}$ carbon source $), 60 \%$ culture medium $+40 \%$ source water $(\sim 20.4 \mathrm{mg} / \mathrm{L}$ carbon source $), 40 \%$ culture medium $+60 \%$ source water ( $\sim 15.6 \mathrm{mg} / \mathrm{L}$ carbon source), $20 \%$ culture medium $+80 \%$ source water $(\sim 10.8 \mathrm{mg} / \mathrm{L}$ carbon source), and $100 \%$ source water ( $\sim 6 \mathrm{mg} / \mathrm{L}$ carbon source), according to Kuznetaov et al. [46]. Kuznetaov et al. defined oligotrophic bacteria that could first survive in a medium with 1-15 mg/L carbon source. Therefore, the isolated aerobic denitrifiers were oligotrophic bacteria. The three aerobic denitrification bacteria, N299, G107, and 81Y, had good nitrogen removal ability and were used to remediate reservoir source water.

Through gradient domestication in source water, the aerobic denitrifiers could adapt to the source water environment. All three strains showed good denitrification characteristics, which was consistent with the results of our previous studies [45]. The nitrate removal rates of N299, G107, and 81Y were $33.69 \%, 28.28 \%$, and $22.86 \%$, respectively, in $48 \mathrm{~h}$. Zhou et al. [45] showed that after $72 \mathrm{~h}$ of cultivation in raw water, the nitrate and total nitrogen removal rates of two strains of aerobic 
denitrifying bacteria were $30 \%-40 \%$ and $20 \%-25 \%$, respectively. After domestication, the bacteria in our experiment reached densities of $10^{6} \mathrm{cfu} / \mathrm{mL}$, which were then used to remediate source water.

Addition of the three aerobic denitrifying strains to the source water increased the rates of nitrite and nitrate reduction, indicating good denitrification performance. Because nitrite is an intermediate of nitrification and denitrification, changes in nitrite levels in the system reflect nitrogen cycling by the bacteria. The nitrate level decreased while the nitrite level increased in a short period in the control system; this indicated that there was a certain number of denitrifying bacteria in the system, which is consistent with the findings of Carter et al. [47]. However, the denitrification performance of the system containing the three domesticated denitrifying strains was superior to that of the control system. The nitrogen in the control system could not be converted into its gaseous form and, hence, could not be removed completely. It was only converted to nitrite and then oxidized to nitrate, and thus it maintained a stable state until the end of the experiment. Previous studies have shown that most aerobic denitrifiers are able to denitrify at a DOC of less than $3 \mathrm{mg} / \mathrm{L}$ [48]. The strains used in our study could tolerate a high DOC of 3-7 mg/L, which is consistent with the findings of our previous study [44].

We evaluated the effect of bacterial growth of the aerobic denitrifying bacteria by using plate counts [44]. In addition, the nitrogen removal performances of the bacteria and the control system reflected the effect of bacterial growth in the experiment. The density of aerobic denitrifying bacteria in the experimental system was significantly higher than that in the control system, indicating that the domesticated aerobic denitrifiers persisted in the source water environment and maintained their denitrification abilities. The TN removal rate in the experimental system averaged $50 \%$, while that in the control system was $20 \%-30 \%$. There were a certain number of denitrifying bacteria in the natural system, which is consistent with the findings of Carter et al. (in a sediment system) [47], Zhang et al. (in canal systems) [22], Kim et al. (in soil systems) [23], Zhu et al. (in pond systems) [24], Joo et al. (in an activated sludge system) [25], Guo et al. (in lake systems) [26], and Huang et al. (in a reservoir system) $[44,45,49]$. Therefore, the TN removal rate in the control system also reached $20 \%-30 \%$. In addition, the COD removal rate was higher in the experimental system than in the control system. Liu et al. [26] showed that the TN decreased slightly when a carbon source was added to the source water at a $\mathrm{C} / \mathrm{N}$ ratio of 4 , mainly due to the exhaustion of the carbon source. In a similar study, $\mathrm{Xu}$ et al. [24] showed that the TN removal rate reached $85 \%$ in filtered source water. Wei et al. [41] reported a TN removal rate of $\sim 40 \%$ in source water over 60 days. $\mathrm{Xu}$ et al. [24] examined the ability of an aerobic denitrifier (Pseudomonas mendocina 3-7) isolated from the Hua-jia-Chi Pond in China to remediate polluted drinking water by performing experiments in different modified DM media, although the strain was not tested in real source water. Overall, the results of our study and those of previous studies suggest that biological agents can remediate source water environments, reduce the environmental impacts of industry and society, and have enormously valuable applications.

The experiment with supplemental bacteria was designed to investigate whether the addition of bacteria could reduce the concentrations of nitrogen or other nutrients and further purify the water. Because of the lack of a carbon source in the system, addition of bacteria did not further remove contaminants and purify the source water. The supplemental carbon experiment was designed to investigate whether the aerobic denitrifying bacteria were still highly active by adding more source water, which simulated a real reservoir environment. The nitrate concentration in the system that received the supplemental carbon showed a significant downward trend, while that in the control 
system did not change. Because the temperature of the experiment was not controlled, the temperature decreased from $21.9-11.4{ }^{\circ} \mathrm{C}$ over the course of the experiment. The denitrification process was sensitive to the temperature, and the denitrification rate doubled with every $4{ }^{\circ} \mathrm{C}$ increase in temperature [50]. Temperature was an important factor, which could have affected the enzymatic activity of aerobic denitrification bacteria [51]. Because of the low temperature, the nitrogen removal rater was not obvious. However, the data showed that the previously added aerobic denitrifying bacteria were still active. The rate of $\mathrm{COD}_{\mathrm{Mn}}$ degradation in the supplemental carbon system was faster than that in the control system, which indicated the heterotrophic characteristics of the flora.

\section{Experimental Section}

\subsection{Samples}

Surface sediments (depth $=0-10 \mathrm{~cm}$ ) and water samples were collected from an oligotrophic reservoir ecosystem (location: $34^{\circ} 56^{\prime} 38.74^{\prime \prime} \mathrm{N}, 117^{\circ} 41^{\prime} 14.13^{\prime \prime} \mathrm{E}$ ) in June 2011 by using a sterilized Petersen stainless steel grab sampler [49]. The samples were stored in black plastic bags at $4{ }^{\circ} \mathrm{C}$ and transferred to the Key Laboratory of Northwest Water Resource, Environment and Ecology, Xi'an University of Architecture and Technology (Xi'an, China).

\subsection{Enrichment Cultures and Isolation of the Aerobic Denitrifiers}

A $100-\mathrm{mL}$ stored sediment sample was added to $700 \mathrm{~mL}$ of the enrichment denitrification broth (in $\mathrm{g} \cdot \mathrm{L}^{-1}: \quad 0.5 \mathrm{CH}_{3} \mathrm{COONa}, \quad 0.1 \quad \mathrm{NaNO}_{3}, \quad 0.1 \quad \mathrm{~K}_{2} \mathrm{HPO}_{4} \cdot 3 \mathrm{H}_{2} \mathrm{O}, 0.05 \mathrm{CaCl}_{2}, 0.05 \quad \mathrm{MgCl}_{2} \cdot 6 \mathrm{H}_{2} \mathrm{O}$; $\mathrm{pH}$ 7.2) $[43,49]$. Every three days, the medium concentration was reduced by $10 \%$ by removing some of the volume and replacing it with an equal volume of water. Enrichment and domestication of the aerobic denitrifiers lasted almost a month [51]. The enrichment sediment suspension was sampled via gradient dilution in triplicate. The gradient dilutions were as follows: $10^{-1}$ dilution $(1 \mathrm{~mL}$ enrichment sludge suspension added to $9 \mathrm{~mL}$ sterile distilled water $), 10^{-2}$ dilution $\left(1 \mathrm{~mL} \cdot 10^{-1}\right.$ dilution suspension added to $9 \mathrm{~mL}$ sterile distilled water), $10^{-3}$ dilution $\left(1 \mathrm{~mL} \cdot 10^{-2}\right.$ dilution suspension added to $9 \mathrm{~mL}$ sterile distilled water), $10^{-4}$ dilution $\left(1 \mathrm{~mL} 10^{-3}\right.$ dilution suspension added to $9 \mathrm{~mL}$ sterile distilled water), $10^{-5}$ dilution ( $1 \mathrm{~mL} 10^{-4}$ dilution suspension added to $9 \mathrm{~mL}$ sterile distilled water), $10^{-6}$ dilution ( $1 \mathrm{~mL} 10^{-5}$ dilution suspension added to $9 \mathrm{~mL}$ sterile distilled water), and $10^{-7}$ dilution ( $1 \mathrm{~mL} 10^{-6}$ dilution suspension added to $9 \mathrm{~mL}$ sterile distilled water). The diluents were streaked on a solid screening medium (in $\mathrm{g} \cdot \mathrm{L}^{-1}: 0.1 \mathrm{CH}_{3} \mathrm{COONa}, 0.02 \mathrm{NaNO}_{3}, 0.02 \mathrm{~K}_{2} \mathrm{HPO}_{4} \cdot 3 \mathrm{H}_{2} \mathrm{O}, 0.01 \mathrm{CaCl}_{2}, 0.01 \mathrm{MgCl}_{2} \cdot 6 \mathrm{H}_{2} \mathrm{O}$, 20 agar; $\mathrm{pH}$ 7.2) [41] and incubated at $30^{\circ} \mathrm{C}$. Prominent single colonies were harvested and subsequently cultivated in $\mathrm{SM}$ medium (in $\mathrm{g} \cdot \mathrm{L}^{-1}$ : $0.1 \mathrm{CH}_{3} \mathrm{COONa}, 0.02 \mathrm{NaNO}_{3}, 0.02 \mathrm{~K}_{2} \mathrm{HPO}_{4} \cdot 3 \mathrm{H}_{2} \mathrm{O}, 0.01 \mathrm{CaCl}_{2}$, $0.01 \mathrm{MgCl}_{2} \cdot 6 \mathrm{H}_{2} \mathrm{O}, \mathrm{pH} 7.2$ ) with $\mathrm{NaNO}_{3}$ as the sole nitrogen source in order to assess the performance of the aerobic denitrifying bacteria. Three isolated strains (N299, G107, and 81Y) with high nitrogen removal performance were obtained and stored on SM slants at $4{ }^{\circ} \mathrm{C}$ and on Glycerin SM at $-20{ }^{\circ} \mathrm{C}$.

\subsection{Analysis of $16 S$ rRNA Gene Sequences}

We performed polymerase chain reaction (PCR) by using the following primers [52]: 7F 5'-CAGAGTTGATCCTGGCT-3' and 1540R 5'-AGGAGGTGATCCAGCCGCA-3'. The PCR mix 
consisted of $2.5 \mu \mathrm{L} 5 \times$ buffer (with $\mathrm{Mg}^{2+}$ ), $0.5 \mu \mathrm{L}$ template, $2.5 \mathrm{mM}$ of each dNTP, $0.2 \mu \mathrm{L}$ Taq DNA polymerase, and sterile nuclease-free water (total volume, $25 \mu \mathrm{L}$ ). The PCR was performed as follows: $4 \mathrm{~min}$ at $94{ }^{\circ} \mathrm{C}$, followed by 30 cycles of denaturation at $94{ }^{\circ} \mathrm{C}$ for $45 \mathrm{~s}$, annealing at $55^{\circ} \mathrm{C}$ for $15 \mathrm{~s}$, and extension at $72{ }^{\circ} \mathrm{C}$ for $1 \mathrm{~min}$. After a final extension at $72{ }^{\circ} \mathrm{C}$ for $10 \mathrm{~min}$, the reaction mixtures were held at $4{ }^{\circ} \mathrm{C}$. We screened the sequences for homology with the sequences in GenBank by using BLAST (http://blast.ncbi.nlm.nih.gov/Blast.cgi). A phylogenetic tree was constructed with the MEGA 5.0 program using the neighbor-joining method with 1000 bootstrap replicates and the maximum composite likelihood model.

\subsection{Domestication of the Aerobic Denitrifiers in the Source Water}

The three isolated aerobic denitrifying bacteria were inoculated into $50 \mathrm{~mL}$ liquid $\mathrm{SM}$ medium in separate $100 \mathrm{~mL}$ Erlenmeyer flasks and cultured for $24 \mathrm{~h}$ at $30{ }^{\circ} \mathrm{C}$ and $120 \mathrm{rpm}$. The aerobic denitrifying bacteria were then domesticated [45] by a series of transfers through the following media concentrations: $100 \%$ culture medium (SM medium), $80 \%$ culture medium $+20 \%$ source water, $60 \%$ culture medium $+40 \%$ source water, $40 \%$ culture medium $+60 \%$ source water, $20 \%$ culture medium $+80 \%$ source water, and $100 \%$ source water. Each gradient domestication medium was sterilized at $121^{\circ} \mathrm{C}$ for 30 min prior to inoculation. We cultured the strains in $150 \mathrm{~mL}$ liquid medium in 250-mL Erlenmeyer flasks. We inoculated new culture media by 10\% volumetric dilution every $48 \mathrm{~h}$. We measured the nitrate and nitrite concentrations of the media to evaluate the performance of domestication. At the end of domestication, we measured the growth ability of the strains by performing plate counts [41] after 5 days of growth at $30{ }^{\circ} \mathrm{C}$ in solid $\mathrm{SM}$ medium (in $\mathrm{g} \cdot \mathrm{L}^{-1}$ : $0.1 \mathrm{CH}_{3} \mathrm{COONa}, 0.02 \mathrm{NaNO}_{3}, 0.02 \mathrm{~K}_{2} \mathrm{HPO}_{4} \cdot 3 \mathrm{H}_{2} \mathrm{O}, 0.01 \mathrm{CaCl}_{2}, 0.01 \mathrm{MgCl}_{2} \cdot 6 \mathrm{H}_{2} \mathrm{O}, 20$ agar; pH 7.2). We determined the dry cell weight (DCW) of the cultures by weighing cell pellets.

\subsection{The 60-Day Source Water Denitrification Experiment}

The experiment was performed in a 20 -L bottle with a black plastic bag on the outer wall to simulate the darkness of the reservoir environment. DOC of the system was controlled using an aeration pump (Songbao, Zongshan, China). The system was maintained at room temperature. The three strains (N299, G107, and 81Y) after gradient domestication were added to the experimental system at $0.4 \mathrm{ppm}(2 \mathrm{~mL} / 20 \mathrm{~L})$. Nitrate, nitrite, TN, COD, and aerobic denitrifying bacterial colonies were measured. All parameters were measured in triplicate. Nitrate, nitrite, and TN were measured every 5 days, and $\mathrm{COD}_{\mathrm{Mn}}$ and number of colonies were measured every 10 days.

\subsection{Experiment with Supplemental Bacteria}

At the end of the 60-day source water denitrification experiment, we supplemented samples of the systems with bacteria to investigate whether adding bacteria could further purify the water. We added $0.4 \mathrm{ppm}$ each of the three domesticated denitrifying bacteria to 5-L samples of the water from the previous 60-day experiment and from the control system. The 5-L bottles were wrapped in black plastic bags to simulate the darkness of the reservoir environment and incubated at $30{ }^{\circ} \mathrm{C}$ for 35 days. 
DOC was not controlled. Nitrate and nitrite were measured every 5 days, and CODMn was measured every 10 days.

\subsection{Supplemental Carbon Experiment}

At the end of the 60-day source water denitrification experiment, we performed a supplemental carbon experiment to investigate whether the aerobic denitrifying bacteria were still highly active. We added $5 \mathrm{~L}$ of water from the 60 -day experiment and $15 \mathrm{~L}$ of fresh source water to 20 -L bottles wrapped in black plastic bags to simulate the darkness of the reservoir environment. Nitrate and nitrite and $\mathrm{COD}_{\mathrm{Mn}}$ were measured to reflect the experimental results. Nitrate and nitrite were measured every 5 days, and $\mathrm{COD}_{\mathrm{Mn}}$ was measured every 10 days.

\subsection{Data Analysis}

The optical density of the culture broth was measured at $600 \mathrm{~nm}$ (OD600) by using a spectrophotometer (DR6000; HACH Company, Loveland, CO, USA) [53]. The nitrite concentration was determined by using $N$-(1-naphthalene)-diaminoethane photometry [54]. The TN and nitrate concentrations were measured by using hydrochloric acid photometry [54]. CODMn was analyzed using the potassium permanganate method [44]. DCW was determined by weighing the cell pellet after 5-mL samples of the broth cultures (SM medium) were dried in an oven at $105{ }^{\circ} \mathrm{C}$ for $12 \mathrm{~h}$ [53]. We used a scanning electron microscope (S-3400N; Hitachi, Tokyo, Japan). The densities of aerobic denitrifying bacteria in the cultures were measured by plate counts [40]. DOC and temperature were measured using HQ30d (HACH Company, Loveland, CO, USA). The samples of nitrate and nitrite were filtered using a $0.45-\mu \mathrm{m}$ cellulose-acetate filter to remove the bacteria.

\section{Conclusions}

Through enrichment and domestication, three oligotrophic aerobic denitrification bacteria were obtained. On the basis of their 16S rRNA sequences, the aerobic denitrifiers were identified as Zoogloea sp. N299, Acinetobacter sp. G107, and Acinetobacter sp. 81Y. During the source-water gradient domestication, the three strains gradually adapted to the source water environment, suggesting that we can optimize domestication strategies to improve source-water denitrification capacity and the ability to adapt to a source of water in order to bioremediate micro-polluted source water.

The bacteria displayed strong denitrification characteristics during the 60 days in the source water. The nitrate concentration in the source water in the experimental system declined by at least $70 \%$, while that in the control system declined by only $20 \%$. There was no accumulation of nitrite in the system. In the subsequent experiment in which additional bacteria were added, there was no apparent difference between the experimental and control systems because of the lack of carbon. In the extension experiment in which additional carbon-containing source water was added, the nitrate removal rate in the experimental system reached $16.97 \%$ after 35 days, while that in the control system reached only $3.01 \%$; this indicated that some aerobic denitrifying bacteria still survived in the source water from the 60-day experiment and maintained strong denitrification capabilities. The results support further experiments to characterize the bioremedial potential of aerobic denitrifying bacteria in 
source water. In order to better simulate the reservoir environment, experiments under additional sediment conditions should be performed.

We used a series of domestication and source-water experiments to show the feasibility of using aerobic denitrifying bacteria to bioremediate micro-polluted source water, suggesting a new way to reduce the environmental pollution load.

\section{Acknowledgments}

This study was funded by the National Science and Technology Pillar Program (Grant No. 2012BAC04B02). Specially thanks to the anonymous reviewers for their valuable remarks on the manuscript.

\section{Author Contributions}

Shi-Lei Zhou carried out the experiment and prepared the first edition of the manuscript. Na Zhou, Shi-Yu Di, Zi-Zhen Zhou, and Lin Guo contributed to the collection and analysis of the experimental data. Ting-Lin Huang and Hai-Han Zhang were involved in the discussion of the results and the final proofreading of the manuscript. All authors have read and approved the final manuscript.

\section{Conflicts of Interest}

The authors declare no conflict of interest.

\section{References}

1. Galloway, J.N.; Townsend, A.R.; Erisman, J.W.; Bekunda, M.; Cai, Z.; Freney, J.R.; Martinelli, L.A.; Seitzinger, S.P.; Sutton, M.A. Transformation of the nitrogen cycle: Recent trends, questions, and potential solutions. Science 2008, 320, 889-892.

2. Duce, R.A.; LaRoche, J.; Altieri, K.; Arrigo, K.R.; Baker, A.R.; Capone, D.G.; Cornell, S.; Dentener, F.; Galloway, J.; Ganeshram, R.S. Impacts of atmospheric anthropogenic nitrogen on the open ocean. Science 2008, 320, 893-897.

3. Tilman, D.; Cassman, K.G.; Matson, P.A.; Naylor, R.; Polasky, S. Agricultural sustainability and intensive production practices. Nature 2002, 418, 671-677.

4. Camargo, J.A.; Alonso, Á. Ecological and toxicological effects of inorganic nitrogen pollution in aquatic ecosystems: A global assessment. Environ. Int. 2006, 32, 831-849.

5. Qin, B.Q.; Zhu, G.W.; Gao, G.; Zhang, Y.L.; Li, W.; Paerl, H.W.; Carmichael, W.W. A drinking water crisis in Lake Taihu, China: Linkage to climatic variability and lake management. Environ. Manag. 2010, 45, 105-112.

6. Jiang, C.L.; Zhu, L.Q.; Hu, X.Q.; Cheng, J.Y.; Xie, M.H. Reasons and control of eutrophication in new reservoirs. In Eutrophication: Causes, Consequences and Control; Springer: Berlin, Germany, 2011; pp. 325-340.

7. Cai, Q.; Hu, Z. Studies on eutrophication problem and control strategy in the Three Gorges Reservoir. Acta Hydrobiol. Sin. 2006, 30, 11. 
8. Li, L.; Wang, H.W.; Lu, J.H. Nitrogen removal using air stripping tower in urban wastewater treatment plant. China Water Wastewater 2006, 22, 92.

9. Huang, H.M.; Song, Q.W.; Wang, W.J.; Wu, S.W.; Dai, J.K. Treatment of anaerobic digester effluents of nylon wastewater through chemical precipitation and a sequencing batch reactor process. J. Environ. Manag. 2012, 101, 68-74.

10. Zhu, G.B.; Peng, Y.Z.; Li, B.K.; Guo, J.H.; Yang, Q.; Wang, S.Y. Biological removal of nitrogen from wastewater. In Reviews of Environmental Contamination and Toxicology; Whitacre, D., Ed.; Springer: New York, NY, USA, 2008; Volume 192, pp. 159-195.

11. Abdul-Rahman, R.; Tsuno, H.; Zainol, N. Nitrogen nutrient removals from wastewater and river water. Water Sci. Technol. 2002, 45, 197-204.

12. Finneran, K.T.; Housewright, M.E.; Lovley, D.R. Multiple influences of nitrate on uranium solubility during bioremediation of uranium-contaminated subsurface sediments. Environ. Microbiol. 2002, 4, 510-516.

13. Sun, W.M.; Cupples, A.M. Diversity of five anaerobic toluene-degrading microbial communities investigated using stable isotope probing. Appl. Environ. Microbiol. 2012, 78, 972-980.

14. Sun, W.M.; Sun, X.X.; Cupples, A.M. Presence, diversity and enumeration of functional genes (bssA and bamA) relating to toluene degradation across a range of redox conditions and inoculum sources. Biodegradation 2014, 25, 189-203.

15. Lovley, D.R. Bioremediation of organic and metal contaminants with dissimilatory metal reduction. J. Ind. Microbiol. 1995, 14, 85-93.

16. Kaspar, H.F. Nitrite reduction to nitrous oxide by propionibacteria: Detoxication mechanism. Arch. Microbiol. 1982, 133, 126-130.

17. Waki, M.; Yasuda, T.; Yokoyama, H.; Hanajima, D.; Ogino, A.; Suzuki, K.; Yamagishi, T.; Suwa, Y.; Tanaka, Y. Nitrogen removal by co-occurring methane oxidation, denitrification, aerobic ammonium oxidation, and anammox. Appl. Microbiol. Biotechnol. 2009, 84, 977-985.

18. Adav, S.S.; Lee, D.J.; Lai, J.Y. Biological nitrification-denitrification with alternating oxic and anoxic operations using aerobic granules. Appl. Microbiol. Biotechnol. 2009, 84, 1181-1189.

19. Adav, S.S.; Lee, D.J.; Lai, J. Enhanced biological denitrification of high concentration of nitrite with supplementary carbon source. Appl. Microbiol. Biotechnol. 2010, 85, 773-778.

20. Van Rijn, J.; Tal, Y.; Schreier, H.J. Denitrification in recirculating systems: Theory and applications. Aquac. Eng. 2006, 34, 364-376.

21. Robertson, L.A.; Kuenen, J.G. Thiosphaera pantotropha gen. nov. sp. nov., a facultatively anaerobic, facultatively autotrophic sulphur bacterium. J. Gen. Microbiol. 1983, 129, 2847-2855.

22. Zhang, D.Y.; Li, W.G.; Huang, X.F.; Qin, W.; Liu, M. Removal of ammonium in surface water at low temperature by a newly isolated Microbacterium sp. Strain SFA13. Bioresour. Technol. 2013, 137, 147-152.

23. Kim, M.; Jeong, S.Y.; Yoon, S.J.; Cho, S.J.; Kim, Y.H.; Kim, M.J.; Ryu, E.Y.; Lee, S.J. Aerobic denitrification of Pseudomonas putida $\mathrm{AD}-21$ at different $\mathrm{C} / \mathrm{N}$ ratios. J. Biosci. Bioeng. 2008, 106, 498-502.

24. Zhu, L.; Ding, W.; Feng, L.J.; Dai, X.; Xu, X.Y. Characteristics of an aerobic denitrifier that utilizes ammonium and nitrate simultaneously under the oligotrophic niche. Environ. Sci. Pollut. Res. 2012, 19, 3185-3191. 
25. Joo, H.S.; Hirai, M.; Shoda, M. Piggery wastewater treatment using Alcaligenes faecalis strain No. 4 with heterotrophic nitrification and aerobic denitrification. Water Res. 2006, 40, 3029-3036.

26. Guo, L.Y.; Chen, Q.K.; Fang, F.; Hu, Z.X.; Wu, J.; Miao, A.J.; Xiao, L.; Chen, X.F.; Yang, L.Y. Application potential of a newly isolated indigenous aerobic denitrifier for nitrate and ammonium removal of eutrophic lake water. Bioresour. Technol. 2013, 142, 45-51.

27. Su, J.J.; Liu, B.Y.; Liu, C.Y. Comparison of aerobic denitrification under high oxygen atmosphere by Thiosphaera pantotropha ATCC 35512 and Pseudomonas stutzeri SU2 newly isolated from the activated sludge of a piggery wastewater treatment system. J. Appl. Microbiol. 2002, 90, 457-462.

28. Joo, H.S.; Hirai, M.; Shoda, M. Characteristics of ammonium removal by heterotrophic nitrification-aerobic denitrification by Alcaligenes faecalis No. 4. J. Biosci. Bioeng. 2005, 100, 184-191.

29. Niel, E.W.J.; Braber, K.J.; Robertson, L.A.; Kuenen, J.G. Heterotrophic nitrification and aerobic denitrification in Alcaligenes faecalis strain TUD. Antonie van Leeuwenhoek 1992, 62, 231-237.

30. Liu, J.J.; Wang, P.; Wang, H. Study on denitrification characteristics of a heterotrophic nitrification-aerobic denitrifier. Res. Environ. Sci. 2008, 21, 121-125.

31. Chen, F.; Xia, Q.; Ju, L.K. Competition between oxygen and nitrate respirations in continuous culture of Pseudomonas aeruginosa performing aerobic denitrification. Biotechnol. Bioeng. 2006, 93, 1069-1078.

32. Huang, H.K.; Tseng, S.K. Nitrate reduction by Citrobacter diversus under aerobic environment. Appl. Microbiol. Biotechnol. 2001, 55, 90-94.

33. Yang, X.P.; Wang, S.M.; Zhang, D.W.; Zhou, L.X. Isolation and nitrogen removal characteristics of an aerobic heterotrophic nitrifying-denitrifying bacterium, Bacillus subtilis A1. Bioresour. Technol. 2011, 102, 854-862.

34. Yu, A.R.; Li, Y.; Yu, J. Denitrification of a newly isolated Bacillus strain W2 and its application in aquaculture. J. Microbiol. 2004, 25, 77-81.

35. Patureau, D.; Helloin, E.; Rustrian, E.; Bouchez, T.; Delgenes, J.P.; Moletta, R. Combined phosphate and nitrogen removal in a sequencing batch reactor using the aerobic denitrifier, Microvirgula aerodenitrificans. Water Res. 2001, 35, 189-197.

36. Barak, Y.; van Rijn, J. Atypical polyphosphate accumulation by the denitrifying bacterium Paracoccus denitrificans. Appl. Environ. Microbiol. 2000, 66, 1209-1212.

37. Obaja, D.; Macé, S.; Mata-Alvarez, J. Biological nutrient removal by a sequencing batch reactor (SBR) using an internal organic carbon source in digested piggery wastewater. Bioresour. Technol. 2005, 96, 7-14.

38. Zhu, L.; Ding, W.; Feng, L.J.; Kong, Y.; Xu, J.; Xu, X.Y. Isolation of aerobic denitrifiers and characterization for their potential application in the bioremediation of oligotrophic ecosystem. Bioresour. Technol. 2012, 108, 1-7.

39. Heaton, T.; Talma, A.; Vogel, J. Origin and history of nitrate in confined groundwater in the western Kalahari. J. Hydrol. 1983, 62, 243-262.

40. Wilson, G.B.; Andrews, J.N.; Bath, A.H. Dissolved gas evidence for denitrification in the Lincolnshire Limestone groundwaters, eastern England. J. Hydrol. 1990, 113, 51-60.

41. Huang, T.L.; Wei, W.; Su, J.F.; Zhang, H.H.; Li, N. Denitrification performance and microbial community structure of a combined WLA-OBCO system. PLOS ONE 2012, 7, e48339. 
42. Wei, W.; Huang, T.L.; Li, N. Denitrification characteristics of in-situ biological inoculation under conditions of low temperature and poor nutrient. Water Technol. 2012, 6, 8-12.

43. Huang, T.L.; Li, N.; Zhang, H.H.; Wang, K.; Liu, T.T. Denitrification characters and safety of communities of cold tolerant oligotrophic and aerobic denitrifying bacteria. Chin. J. Environ. Eng. 2013, 7, 2419-2423.

44. Huang, T.L.; Wei, W.; Wang, C.Y.; Huang, Z.; Su, J.F.; Li, Z. Pilot research on micropollutants removal in the raw water by combined process of water-lifting aeration and oligotrophic biofilm. J. Chongqing Univ. 2012, 35, 125-146.

45. Huang, T.L.; Zhou, N.; Zhang, H.H.; Di, S.Y.; Zhou, S.L.; Guo, L. Isolation and identification of three oligotrophic aerobic denitrifying bacteria and denitrification characteristics. Chin. J. Environ. Eng. 2014, 8, 5507-5513.

46. Kuznetsov, S.; Dubinina, G.; Lapteva, N. Biology of oligotrophic bacteria. Annu. Rev. Microbiol. 1979, 33, 377-387.

47. Carter, J.P.; Hsaio, Y.; Spiro, S.; Richardson, D.J. Soil and sediment bacteria capable of aerobic nitrate respiration. Appl. Environ. Microbiol. 1995, 61, 2852-2858.

48. Su, J.J.; Liu, B.Y.; Lin, J.; Yang, C.P. Isolation of an aerobic denitrifying bacterial strain NS2 from the activated sludge of piggery wastewater treatment systems in Taiwan possessing denitrification under 92\% oxygen atmosphere. J. Appl. Microbiol. 2001, 91, 853-860.

49. Wei, W.; Huang, T.L.; Su, J.F.; Wang, C.Y.; Huang, Z.; Li, N. Isolation and identification of an oligotrophic and aerobic denitrification and its denitrification characteristics. Ecol. Environ. Sci. 2010, 19, 2166-2171.

50. Zaitsev, G.; Mettänen, T.; Langwaldt, J. Removal of ammonium and nitrate from cold inorganic mine water by fixed-bed biofilm reactors. Miner. Eng. 2008, 21, 10-15.

51. Wei, W. Properties and Experiments of Enhanced in-situ Biological Nitrogen Removal by Lifting Water and Aeration for Micro-Polluted Raw Water. Ph.D. Thesis, Xi'an University of Architecture \& Technology, Xi'an, China, 2011; pp. 26-27.

52. Tan, L.; Zhang, X.Y.; Cao, T.L.; Gai, D.Y.; Tian, X.D. Isolation and identification of a new strain acidophilic heterotrophic bacteria from stone coal drainage. Adv. Mater. Res. 2012, 518, 598-603.

53. Kim, J.K.; Park, K.J.; Cho, K.S.; Nam, S.W.; Park, T.J.; Bajpai, R. Aerobic nitrification-denitrification by heterotrophic Bacillus strains. Bioresour. Technol. 2005, 96, 1897-1906.

54. Chen, X.F.; Yang, L.Y.; Xiao, L.; Miao, A.J.; Xi, B.D. Nitrogen removal by denitrification during cyanobacterial bloom in Lake Taihu. J. Freshw. Ecol. 2012, 27, 243-258.

(C) 2015 by the authors; licensee MDPI, Basel, Switzerland. This article is an open access article distributed under the terms and conditions of the Creative Commons Attribution license (http://creativecommons.org/licenses/by/4.0/). 